\title{
DEEP LEGAL PLURALISM DALAM KONSEP PERKEMBANGAN ANTROPOLOGI HUKUM
}

\author{
Nama:Nabila nazifah \\ Email:nabilanazifah111@gmail.com \\ BP:2110003600278 \\ Universitas Ekasakti Padang
}

\section{A.PENDAHULUAN}

Perkembangan hukum nasional di indonesia berlangsung berseiring dengan perkembangan kekuasaan negara-negara bangsa. Tak terelak lagi kenyataannya memang demikian, karena apa yang disebut hukum nasional itu pada hakekatnya adalah hukum yang pengesahan pembentukan dan pelaksanaannya bersumber dari kekuasaan dan kewibawaan negara. Tatkala kehidupan berkembang ke dalam skala-skala yang lebih luas, dari lingkarlingkar kehidupan komunitas lokal (old societies) ke lingkar-lingkar besar yang bersifat translokal pada tataran kehidupan berbangsa yang diorganisasi sebagai suatu komunitas politik yang disebut negara bangsa yang modern (new nation state), kebutuhan akan suatu sistem hukum yang satu dan pasti (alias positif!) amatlah terasa. Maka gerakan ke arah unifikasi dan kodifikasi hukum terlihat marak di sini, seolah menjadi bagian intheren dari proses nasionalisasi dan negaranisasi serta modernisasi yang amat mengesankan telah terjadinya pengingkaran eksistensi apapun yang berbau lokal dan tradisional.

Tidak ada keraguan bahwa ungkapan 'bangsa pelangi' adalah, dan masih, metafora yang diucapkan untuk persatuan Afrika Selatan, yang dimaksudkan untuk menyatukan bangsa yang sangat terpecah di mana terdapat perpecahan yang ketat antara kelompok-kelompok ras. Meskipun demikian, apartheid mungkin telah dihapuskan tetapi ikatan masyarakat Afrika Selatan tetap terpecah di sepanjang garis budaya dan agama. Sistem hukum Afrika Selatan masih melambangkan perpecahan ini. Misalnya, anggota komunitas budaya dan agama (sebelumnya dipaksa untuk hidup bersama sebagai akibat apartheid) menjalankan aspek-aspek tertentu dari hukum mereka sendiri yang umumnya tidak diakui oleh hukum kami.

Fenomena ini dikenal sebagai 'pluralisme hukum yang dalam'. Persaudaraan hukum dihadapkan pada kompleksitas pluralisme hukum seharihari.Konstitusi menetapkan bahwa negara dapat mengeluarkan undangundang yang mengakui sistem hukum pribadi dan keluarga yang konsisten dengan dan tunduk pada ketentuan lain dalam Konstitusi. Namun, tidak ada 
tanggung jawab pemerintah untuk memasukkan hukum budaya atau agama ke dalam undang-undang negara bagian, dan sejauh ini negara belum melakukannya. Peradilan kurang pasif dalam memberikan perlindungan individu yang termasuk dalam kelompok agama atau budaya jika diperlukan.

Presentasi ini membahas tentang perubahan kebijakan peradilan terkait aspek hukum agama keluarga dan kontribusi lembaga peradilan terhadap munculnya pluralisme hukum yang mendalam di Afrika Selatan. Penekanannya adalah pada yurisprudensi yang berhubungan dengan hukum agama keluarga, dan hukum keluarga Muslim yang lebih khusus, yang mencapai puncaknya dalam Hassam v. Jacobs 2009.

\section{B.PEMBAHASAN}

Prof. Dr. Sulistyowati Irianto, MA

Disampaikan dalam Semina rtentang "Pluralisme Hukum dan Tantangannya Bagi Pembentukan Sistem Hukum Nasional", kerjasama Badan Pembinaan Hukum Nasional Dephum Ham,FH Universitas Hasanuddin, dan Kantor Wilayah Dephuk HAM Sulasesi Selatan, Makasar, 1-2 Mei 2007 Membaca tema seminar "Pluralisme Hukum dan Tantangannya Bagi Pembentukan Sistem Hukum Nasional", saya agak bertanya-tanya.

Dalam judul itu seolah-olah ada dua hal yang berbeda dan bahkan kontradiktif antara "pluralisme hukum" di satu sisi dan pembentukan sistem hukum nasional di sisi yang lain.Oleh karena itu, saya merasa perlu untuk menguraikan secara agak mendasar tentang pluralisme hukum sebagai suatu konsep ilmiah dan pendekatan teoretis dan bagaimana pluralisme hukum diartikan secara berbeda-beda atau"bergerak"seiring dengan perkembangan masyarakat, khususnya fenomena globalisasi dewasa ini.Dengan demikian saya akan mengulas pluralisme hukum sebagai suatu konsep akademik,tidak sebagai konsep yang bernuansa politik praktis.

Sebagai suatu konsep akademik, pengertian pluralisme hukum terus berubah dan dipertajam melalui berbagai perdebatan dalam konferensi dan pertemuan ilmiah para ahli,yang terus menerus melakukan penelitian dalam ranah hukum dan kemasyarakatan (socio-legal studies). Pengertian pluralisme hukum pada masa awal sangat berbeda dengan masa sekarang. Pada masa awal pluralisme hukum diartikan sebagai ko-eksistensi antara berbagai sistem hukum dalam lapangan sosial tertentu yang dikaji. Dalam hal ini para ahli 
"sekedar" melakukan pemetaan terhadap keanekaragaman hukum dalam lapangan kajian tertentu (mapping of legal universe).

Namun pada saat ini pendekatan pluralisme hukum dalam perspektif global memandang pendekatan lama itu tidak dapat digunakan lagi. Paradigma baru dalam pluralisme hukum sangat berkaitan dengan fenomena globalisasi, di mana hukum dari berbagai level bergerak memasuki wilayah-wilayah yang tanpa batas, dan terjadi persentuhan dan adopsi yang kuat di antara hukum internasional, transnasional, nasional dan lokal. Dalam keadaan ini tidak mungkin lagi dapat dibuat suatu pemetaan seolah- olah hukum tertentu (internasional, nasional, lokal) merupakan entitas yang jelas dengan garis-garis batas yang tegas dan terpisah dari sistem hukum yang lain. Sebelum lebih jauh menguraikan tentang bagaimana pluralisme hukum dalam perspektif global, akan diuraikan terlebih dahulu sejarah kemunculan konsep pluralisme hukum dalam literatur antropologi hukum, bagaimana pengertian pluralisme hukum terus berkembang melalui perdebatan para ahli, sampai pada saat ini di mana pengertian pluralisme hukum sangat terkait dengan munculnya fenomena globalisasi.

\section{Sejarah Perkembangan Pendekatan Pluralisme Hukum}

Pada masa awal pluralilsme hukum sebagai suatu pendekatan teoretis muncul dari dua hal. Pertama adalah kebutuhan praktis untuk menjelaskan adanya fenomena keanekaragaman hukum setelah banyak negara-negara memerdekakan diri dari penjajahan dan mewarisi sistem hukum dari negara kolonial, di samping sistem hukum rakyat yang telah ada. Kedua, kebutuhan akademik sebagai jawaban yang kritikal terhadap pandangan legal centralism, suatu pandangan yang menyatakan bahwa law is and should be the law of the state, uniform for all persons, exclusive of all other law and administered by a single set of state institutions (John Griffith, 1986).

\section{Pluralisme Hukum pada Masa Awal}

Bila pada pertengahan abad ke-19 keanekaragaman sistem hukum yang dianut oleh masyarakat di berbagai belahan dunia ini ditanggapi sebagai gejala evolusi hukum, maka pada abad ke-20 keanekaragaman tersebut ditanggapi sebagai gejala pluralisme hukum. Kebutuhan untuk menjelaskan gejala ini muncul terutama ketika banyak negara memerdekakan diri dari penjajahan, dan sistem hukum Eropa ditinggalkan di negara-negara tersebut. 
Para legal pluralist pada masa permulaan (1960- 1970 an) mengajukan konsep pluralisme hukum yang meskipun agak bervariasi, namun pada dasarnya mengacu pada adanya ko-eksistensi di antara beberapa sistem hukum yang berada dalam lapangan sosial yang sama. Sebagai contoh adalah konsep yang dikemukakan oleh Sally Engle Merry, pluralisme hukum adalah "is generally defined as a situation in which two or more legal systems coexist in the same social field" (Merry, 1988: 870). Contoh lain adalah konsep klasik dari John Grifiths, yang mengacu pada adanya lebih dari satu tatanan hukum dalam suatu arena sosial. "By 'legal pluralism' I mean the presence in a social field of more than one legal order" (Griffiths, 1986: 1).

Pada masa awal itu yang dilakukan oleh para ahli adalah melakukan identifikasi atau pemetaan terhadap keanekaragaman hukum dalam bidang sosial tertentu (mapping of legal universe). Pengertian pluralisme hukum dicirikan sebagai adanya hukum negara di satu sisi, dan hukum rakyat di sisi yang lain. Hukum rakyat dalam hal ini adalah hukum yang pada prinsipnya tidak berasal dari negara, yaitu hukum adat, hukum agama, kebiasaan-kebiasaan atau kesepakatan dan konvensi sosial lain yang dipandang mengikat sebagai hukum. Pandangan pluralisme hukum dapat menjelaskan bagaimanakah hukum yang beranekaragam secara bersama-sama mengatur suatu bidang kehidupan atau perkara.

Bagi kebanyakan sarjana hukum, kenyataan adanya sistem hukum lain di samping hukum negara masih sulit diterima. Padahal dalam kenyataan seharihari tidak dapat dipungkiri adanya sistem-sistem hukum lain di luar hukum negara (state law). Melalui pandangan pluralisme hukum, dapat diamati bagaimanakah semua sistem hukum tersebut "beroperasi" bersama-sama dalam kehidupan sehari-hari. Artinya, dalam konteks apakah orang memilih aturan hukum tertentu, dan dalam konteks apa ia memilih aturan hukum lain atau kombinasi dari beberapa aturan hukum, dalam kehidupan sehari-hari atau penyelesaian sengketa.Selanjutnya Griffiths membedakan adanya dua macam pluralisme hukum yaitu:weak legal pluralism dan strong legal pluralism (1986). Anne Griffiths menyebutnya sebagai "juristic" atau "classic" (Griffiths, 2005) Menurut Griffiths pluralisme hukum yang lemah itu adalah bentuk lain dari sentralisme hukum karena meskipun mengakui adanya pluralisme hukum, tetapi tetap berpegang pada souveregnity hukum Negara, hukum-hukum yang lain disatukan dalam hierarki di bawah hukum negara. Contoh dari pandangan pluralisme hukum yang lemah adalah konsep yang diajukan oleh Hooker : "The term legal pluralism refers to the situation in which two or more laws interact" (Hooker, 1975: 3). Meskipun mengakui adanya keanekaragaman sistem 
hukum, tetapi ia masih menekankan adanya pertentangan antara apa yang disebut sebagai municipal law sebagai sistem yang dominan (hukum negara), dengan servient law yang menurutnya inferior seperti kebiasaan dan hukum agama.

Sementara itu konsep pluralisme hukum yang kuat, yang menurut Griffiths merupakan produk dari para ilmuwan sosial, adalah pengamatan ilmiah mengenai fakta adanya kemajemukan tatanan hukum yang terdapat di semua (kelompok) masyarakat. Semua sistem hukum yang ada dipandang sama kedudukannya dalam masyarakat, tidak terdapat hierarkhi yang menunjukkan sistem hukum yang satu lebih tinggi dari yang lain. Anne Griffiths menyebutnya "strong", "deep", atau "new" legal pluralism, (Griffiths, 2005) yang mengatakan bahwa semua hukum yang hidup dalam arena sosial masyarakat itu, sama keberlakuannya, tidak ada jaminan bahwa kedudukan hukum yang satu dipandang lebih tinggi daripada hukum yang lain.

John Griffiths (1986) memasukkan pandangan beberapa ahli ke dalam pluralisme hukum yang kuat antara lain adalah teori dari Sally Falk Moore mengenai pembentukan aturan dengan disertai kekuatan pemaksa di dalam kelompok-kelompok sosial yang diberi label the semi-autonomous social field. Dalam hal in Griffiths mengadopsi pengertian pluralisme hukum dari Moore: "Legal pluralism refers to the normative heterogeneity attendant upon the fact that social action always takes place in a contextofmultiple,overlapping'semiautonomoussocialfield". Sementara itu pengertian hukumdari Moore yang juga dikutipnya adalah: "Law is the self-regulation of a 'semi-autonomous social field" (Griffiths, 1986, Tamanaha, 1993: 24-25)

Meskipun masih sering menjadi acuan, pandangan legal pluralist permulaan itu kemudian mendapat kritik terutama dari sarjana hukum konvensional (Tamanaha, 1993, Kleinhans dan MacDonald, 1997). Menurut Tamanaha sebenarnya konsep pluralisme hukum bukanlah hal yang baru, karena Eugene Ehrlich telah membicarakan hal yang sama sejak lama, ketika ia berbicara mengenai konsep living law itu. Dalam salah satu kritiknya terhadap pandangan pluralisme hukum, Tamanaha yang lebih suka menggunakan istilah "rule system pluralism" untuk menggantikan istilah "legal pluralism", mengatakan bahwa pandangan kaum legal pluralist cenderung menonjolkan adanya kontras antara hukum negara dan hukum rakyat (1993: 31). Sebaliknya, menurut kaum legal pluralist, justru sebagian kalangan sarjana hukum sendiri 
yang mengatakan bahwa karakteristik yang paling utama dari folk law adalah, ia tidak diturunkan dari negara (Woodman, 1993: 2).

Pada masa ini studi antropologi hukum, khususnya studi tentang sengketa, ditandai oleh kajian yang mengemukakan kehadiran hukum Negara di samping hukum rakyat. Dalam hal ini ditunjukkan adanya pilihan-pilihan hukum yang terbentang di antara hukum Negara dan hukum rakyat (hukum adat atau hukum agama dan kebiasaan-kebiasaan lain). Pada masa-masa sebelumnya studi sengketa dalam literature antropologi hukum kebanyakan melihat proses penyelesaian yang dilakukan oleh para otoritas adat (the chief, big man, the head man), di luar pengadilan Negara.

\section{Perkembangan Kemudian (1990-an)}

Kemudian berkembang konsep pluralisme hukum yang tidak lagi menonjolkan dikotomi antara sistem hukum negara di satu sisi dan sistem hukum rakyat di sisi yang lain. Pada tahap ini konsep pluralisme hukum lebih menekankan pada "a variety of interacting, competing normative orders -each mutually influencing the emergence and operation of each other's rules, processes and institutions" (Kleinhans dan MacDonald, 1997: 31). Franz von Benda-Beckmann adalah salah satu ahli yang dapat digolongkan ke dalam tahap perkembangan ini. la mengatakan bahwa tidak cukup untuk sekedar menunjukkan bahwa di lapangan sosial tertentu terdapat keanekaragaman hukum, namun yang lebih penting adalah apakah yang terkandung dalam keanekaragaman hukum tersebut, bagaimanakah sistem-sistem hukum tersebut saling berinteraksi (mempengaruhi) satu sama lain, dan bagaimanakah keberadaan dari sistemsistem hukum yang beragam itu secara bersama-sama dalam suatu lapangan kajian tertentu (F. Benda- Beckmann, 1990:2). Pemikiran di atas sekaligus juga menunjukkan segi-segi metodologis, yaitu cara bagaimana melakukan kajian terhadap keberagaman system hukum dalam suatu lapangan kajian tertentu.

Adat basandi sarak, sarak basandi Kitabullah, suatu "adagium" yang hidup di ranah Minagkabau,menunjukkan adanya interaksi yang sangat erat antara hukum adat dan hukum agama.Demikian pula temuan Franz dan Keebet von Benda Beckmann,yang menunjukkan bahwa $80 \%$ putusan hakim pengadilan negeri di Sumatera Barat berisi hukum adat, menunjukkan bahwa telah terjadi saling pengaruh diantara hukum Negara dan hukum adat(19..).

Persentuhandiantaraberbagaimacamsystem hukum ini mulai mendapat perhatian yang luas di kalangan para ahli.Pengertian konsep pluralisme hukum pada tahap ini (akhir 1990-an) juga dikaitkan dengan tataran individu yang 
menjadi subyek dari pluralisme hukum tersebut. Lihatlah bagaimana Gordon Woodman mengajukan konsepnya:

Legal pluralism in general may be defined as the state of affairs in which a category of social relations is within the fields of operation of two or more bodies of legal norms. Alternatively, if it is viewed not from above in the process of mapping the legal universe but rather from the perspective of the individual subject of law, legal pluralism may be said to exist whenever a person is subject to more than one body of law (Woodman dalam Kleinhans dan MacDonald, 1997: 31, Woodman, 2004)

Menurut hemat saya, munculnya pendekatan yang tidak mendasarkan diri semata pada mapping of the legal universe, merupakan masukan yang cukup berarti dalam rangka mencari pendekatan yang dapat menyederhanakan gejala hukum yang rumit dalam masyarakat. Lihatlah bahwa pluralisme hukum juga terdapat dalam sistem hukum rakyat (folklaw),seperti hukum agama,adat,dan kebiasaan- kebiasaan lain yang saling "bersaing".

Sementara itu sistem hukum negara juga plural sifatnya.Pluralisme dalam hukum negara tidak saja berasal dari pembagian jurisdiksi normatif secara formal seperti pengaturan pada badan-badan korporasi, lembaga-lembaga politik, badan-badan ekonomi, dan badan-badan administrasi yang berada dalam satu sistem, tetapi juga dalam banyak situasi dapat dijumpai adanya choice of law, bahkan conflict of law. Pada prinsipnya state law itself typically comprises multiple bodies of law, with multiple institutional reflections and multiple sources of legitimacy (Kleinhans dan MacDonald, 1997: 32).

\section{Pluralisme Hukum Dalam Perspektif Global}

Pada masa sekarang ini, pandangan legal pluralism mengalami suatu perkembangan yang luar biasa berkenaan dengan adanya fenomena globalisasi dan perdagangan bebas sejak berakhirnya "Perang Dingin". Berbagai perdebatan dan diskusi telah melahirkan pemikiran-pemikiran baru yang lebih tajam dan berarti dalam menganalisis fenomena hukum dalam masyarakat dari berbagai penjuru dunia. Dalam era globalisasi ini telah terjadi pertukaran uang, barang dan jasa melalui perdagangan bebas dan berbagai aktivitas bisnis secara luas. Hal ini sangat didukung oleh adanya kemajuan teknologi informasi yang juga sangat pesat. Hampir tidak ada lagi negara yang dapat hidup sendirian tanpa melakukan transaksi ekonomi dengan negara lain sekarang ini. Kebijakan pasar bebas yang "diprakarsai" terutamaolehnegaranegaramaju("kaya"),telahmenyebabkankitamenjadisuatuwarga pasar dunia 
yang besar. Hampir semua barang dan jasa dari manapun dapat ditemukan dimanapun.

Efek globalisasi juga dapat sangat terlihat dalam bidang hukum.Telah terjadi pertukaran yang luar biasa dalam bidang hukum, di mana suatu hukum dari wilayah tertentu dapat menembus ke wilayah-wilayah lain yang tanpa batas.Hukum internasional dan transnacional dapat menembus ke wilayah negara-negara manapun, bahkan wilayah lokal yang manapun di akar rumput.Atau sebaliknya, bukan hal yang mustahil bila hukum lokal diadopsi sebagian atau seluruhnya menjadi hukum internasional. Terjadi interaksi,Inter.- relasi, saling pengaruh, saling adopsi, tumpang tindih yang sangat rumit di antara hukum internasional, nasional, dan local.

Seorang berkebangsaan Indonesia dapat berdagang dengan seorang berkebangsaan Meksiko, dan mereka dapat mengadakan perjanjian dagang transnational untuk keperluan tersebut. Hukum yang muncul dari transaksi perdagangan inilah yang antara lain dikenal sebagai transnational law. Atau hukum yang mengatur bidang transportasi yang dianut di wilayah Bogota, misalnya, dapat "dipinjam"oleh warga Jakarta untuk diterapkan di wilayahnya sendiri, dan inilah yang dikenal sebagai transnasionalized law. Dengan demikian, hukum bergerak sangat dinamis karena dapat berubah sepanjang waktu.

Globalisasi hukum tidak saja memunculkan persoalan-persoalan global, tetapi juga menyebabkan hukum internasional tidak hanya mengatur soal-soal kenegaraan saja, tetapi juga mengatur kerjasama non-kenegaraan yang berkaitan dengan intervensi humanitarian, promosi nilai-nilai demokrasi, "rule of law", dan "transntional accountability" (Benda-Beckmann, et.al. 2005:

5)Dalam soal hak asasi manusia misalnya, Deklarasi Hak Asasi Manusia sedunia yang dikumandangkan sejak tahun 1948, diikuti oleh berbagai konvensi internasional dan deklarasi yang memuat prinisip-prinsip hak asasi manusia yang lahir kemudian sampai hari ini. Kita dapat melihat bagaimana kuatnya instrument hukum internasional itu mempengaruhi negara-negara terutama anggota Perserikatan Bangsa-Bangsa (PBB) (Merry, 2005: 177-198). Mereka diharapkan untuk dapat ikut serta menandatangani dan meratifikasi instrument hukum internasional tersebut. Artinya, mereka diharapkan membuat instrument hukum di negara masing-masing yang menganut prinsipprinsip penegakan hak asasi manusia, atau hak asasi perempuan, seperti yang dimuat dalam kesepakatan internasional. 
Di samping itu, mereka juga diwajibkan untuk mengubah hukum nasional yang tidak cocok dengan prinsip-prinsip hak asasi manusia dan hak asasi peremppuan. Apakah kita melihat keberadaan instrument hukum hak asasi manusia[6] dalam hukum nasional Indonesia dalam kerangka pemikiran pluralisme hukum ini, yaitu adanya pengaruh hukum internasional terhadap hukum nasional ? Selanjutnya dapat diamati bagaimana hukum internasional, nasional berkenaan dengan hak asasi manusia berimplementasi sampai ke akar rumput. Ketika ada warga masyarakat yang "berteriak" karena merasa hak asasinya dilanggar, maka kita tidak bisa tahu lagi, apakah yang dimaksud dengan hak asasi yang dia perjuangkan itu, mengacu pada hukum internasional, hukum nasional, atau hukum lokal nya sendiri ?

Sistem hukum lokal pun dapat diadopsi ke dalam hukum berskala internasional. Bila hari ini lapangan praktik hukum modern mengembangkan Alterrnative Dispute Resolution (ADR), ada baiknya untuk mencermatinya sebagai bidang yang bersentuhan dengan studi sengketa yang terus dipelajari dari perspektif antropologi hukum. Prinsip-prinsip dalam ADR dapat ditemukan dalam karakter sengketa yang dipelajari secara antropologis. Penyelesaian sengketa bertujuan untuk mencapai win-sin solution (compromise) di mana semua pihak merasa diuntungkan dan dimenangkan (Nader and Todd, 1978). Berbeda dengan sengketa dalam hukum Eropa Barat (atau yang mengadopsinya),yang dilandasi prinsip equality before the law, siapapun diperlakukan sama di muka hukum. Konsekuensinya dalam sengketa adalah, siapa saja yang bersalah akan dinyatakan kalah dan sebaliknya yang benar akan menang. Sebaliknya pada masyarakat dengan sistem hukum "non-Barat", prinsip win-lose di akhir sengketa tidak diinginkan, karena adanya budaya malu, atau takut kehilangan muka.Itu sebabnya banyak sekali sengketa yang diputuskan oleh pengadilan Negara, bahkan pada tingkat kasasi sekalipun, tetapi dalam prakteknya sungguh-sungguh tidak mendamaikan para pihak yang berselisih.Sekarang ADR banyak dipelajari dan dikembangkan di berbagai masyarakat manapun di dunia ini. Bisa juga terjadi mekanisme penyelesaian sengketa di masyarakat lokal tertentu "dipinjam" oleh masyarakat lokal yang lain (Borrowing modes of dispute resolution, Benda-Beckmann, et all, 2005: 2)

Dengan demikian, ciri pluralisme hukum dalam perspektif global adalah memberi perhatian kepada terjadinya saling ketergantungan, adopsi, atau saling pengaruh (interdependensi, interfaces) antara berbagai sistem hukum. Interdependensi yang dimaksud terutama adalah antara hukum internasional, nasional, dan hukum lokal. Kajian-kajian yang berkembang dalam antropologi hukum "baru" mulai melihat bagaimanakah kebijakan dan kesepakatan- 
kesepakatan internasional memberi pengaruh atau bersinggungan dengan sistem hukum dan kebijakan ditingkat nasional, dans elanjutnya memberiimbas kepada sistem hukum dan kebijakan di tingkat lokal. Dalam hal ini barangkali akan muncul pertanyaan, apakah maksudnya bahwa sistem hukum yang berbeda itu saling berketergantungan dan mempengaruhi satu sama lain, sehingga suatu sistem hukum tertentu tidak dapat dipandang sebagai suatu entitas yang jelas batas-batasnya karena sudah berbaur satu sama lain ?

[7]Saya akan mengingatkan kembali mengenai konsepsi hukum yang banyak disepakati di kalangan antropolog hukum, yaitu hukum adalah proposisi yang mengandung konsepsi normative dan konsepsi kognitif (F.Benda-Beckmann, 1986). Sebagai contoh, dalam konsepsi normative, tindakan pembunuhan atau korupsi dilarang oleh semua system hukum, baik Negara, agama, adat maupun kebiasaan lain. Namun kognisi tentang apa yang disebut sebagai "membunuh" atau "korupsi" bisa sangat berbeda di antara berbagai sistem hukum tersebut. Bagi orang Madura atau Bugis yang merasa terlanggar harga dirinya, perbuatan carok atau pembelaan diri karena sirri, barangkali tidak akan dikognisikan sebagai perbuatan terlarang. Demikian pula kognisi mengenai "korupsi" menjadi sangat multi interpretative tergantung pada banyak kepentingan dan relasi kekuasaan.

Pada masa sekarang konsep hukum yang mengacu pada konsepsi normatieve dan cognitive ini digunakan kembali untuk menguraikan kerumitan dalam menjelaskan pluralisme hukum. Hukum dipandang terdiri atas komponenkomponen, bagian-bagian atau cluster (K.Benda-Beckmann, 2002). Hendaknya melihat bahwa cluster, komponen atau bagian-bagian dari hukum inilah yang saling berpengaruh, dan berinteraksi membentuk konfigurasi pluralisme hukum.Selanjutnya saya akan kembali pada kerumitan pembahasan mengenai pluralisme hukum dengan mengacu pada uraian yang dikemukakan oleh Keebet von Benda-Beckmann (2002). Kerumitan itu disebabkan oleh fakta mengenai banyaknya konstelasi pluralisme hukum yang dicirikan oleh besarnya keragaman dalam karakter sistemik masing-masing cluster. Seperti yang dikatakan oleh Keebet "In fact, many constellation sof legal pluralism are characterized by great diversity in the systemic character of each of its components" (K. Benda-Beckmann, 2002: 1) Konteks hukumnya mungkin jelas (hukum negara atau hukum adat), tetapi keberadaan system hukum secara bersama-sama itu menunjukkan adanya saling difusi, kompetisi, dan tentu saja perubahan sepanjang waktu. 
Seberapa jauh sistem hukum saling ber"difusi", dan ber"kompetisi", dan terjadi perubahan sebagai konsekuensinya, sangatlah bervariasi, tergantung pada konteks geografi dan ruang lingkup substansi hukum apa. Keragaman itu akan ditemukan dalam hal institusi dan jenis-jenis aktor yang terlibat, dan kekuatannya dalam saling pengaruh itu akan sangat berbeda. Cluster atau bagian-bagian dari sistem-sistem hukum itu saling berkaitan, menjadi saling bersentuhan, lebur, memberi respons satu sama lain, dan berkombinasi sepanjang waktu.

Apa akibatnya ? Sebelumnya, orang dapat dengan jelas mendefinisikan hukum (yang terdiri dari komponen atau cluster), sebagai hukum adat, hukum agama, atau hukum negara. Pada tahun 1950 -an atau 1960-an, menurut Keebet, banyak usaha-usaha untuk menunjukkan bahwa kebiasaan-kebiasaan local juga dapat dipandang sebagai hukum. Meskipun dasar legitimasinya berbeda dari hukum negara, tetapi tidak ada perbedaan yang mendasar antara hukum negara dan hukm rakyat. Pada tahun 1978 Holleman mengatakan bahwa di wilayah urban di negara-negara berkembang, berkembang bentuk- bentuk hukum baru yang tidak dapat diberi label sebagai hukum negara, hukum adat, atau hukum agama, sehingga disebut sebagai hybrid law, dan banyak pengarang lain menyebutnya unnamed law.

Dengan demikian argumen yang mengatakan bahwa lapangan pluralisme hukum terdiri dari system- sistem hukum yang dapat dibedakan batasnya, tidak laku lagi. Terlalu banyak fragmentasi, overlap dan ketidakjelasan. Batas antara hukum yang satu dan yang lain menjadi kabur, dan hal ini merupakan proses yang dinamis (K.Benda-Beckmann, 2002).

Secara konseptual ada beberapa pokok bahasan penting dalam pemikiran pluralisme hukum "mutakhir", yang akan diuraikan satu persatu.

Pertama, hukum dipandang sangat memainkan peranan penting dalam globalisasi, karena hukum bersentuhan dengan domain sosial, politik, ekonomi. Dapat dipelajari bagaimana hubungan antara relasi kekuasaan dan hukum, dan bagaimana hukum menjadi kekuatan yang sangat besar dalam mendefinisikan kepentingan politik dan ekonomi dalam pergaulan antar kelompok dan bahkan antar bangsa.

Kedua, siapa yang "menggerakkan" hukum ? Dalam "globalisasi hukum" dapat dijumpai adanya mobilitas aktor dan organisasi yang menjadi agent bagi lalu lintas bergeraknya hukum. Contohnya adalah para (buruh) migrant yang "membawa " hukumnya sendiri ke negara tujuan, orang-orang yang sering berada di berbagai negara (pedagang, ekspatriat), pegawai negeri (para 
diplomat ?), NGO internasional, usaha dagang, dan mereka yang dapat berhubungan dengan dunia luar karena fasilitas

alat komunikasi. Aktor-aktor inilah yang membuat hukum bergerak. Merekalah aktor yang penting dalam menciptakan glocalizing process (Benda-Beckmann, et.al, 2005: 8 )

Ketiga, pemahaman globalisasi dalam konteks sejarah sangatlah penting. Globalisasi hukum sudah terjadi sejak dahulu, seiring dengan penjajahan dan perdagangan pada masa silam. Perlu juga melihat bahwa globalisasi hukum tidak hanya dapat dijumpai dalam ekspansi hukum Eropa, tetapi juga tersebarnya hukum Islam ke kawasan-kawasan Asia dan Afika sebelum dan sesudah masa kekuasaan kolonial Eropa. Di samping itu, sepanjang sejarah dapat dilihat bagaimana hukum internasional dan traktat juga menyebabkan hukum "bergerak"

Keempat, berkaitan dengan soal metodologi (khususnya etnografi). Studi pluralisme hukum "baru" memperhatikan mata rantai interaksi yang menghubungkan aktor transnational, nasional dan lokal yang melakukan negosiasi dalam arena multi-sited, dan didasarkan pada relasi-relasi kekuasaan. Sangat penting untuk melihat bagaimana relasi kekuasaan itu menstrukturkan interaksi, dan bagaimana interaksi diproduksi dan dirubah oleh aktor-aktor tersebut (Benda-Beckmann, et.al, 2005: 9)

Etnografi konvensional yang didasarkan pada studi mikro local, yang hanya berpusat pada kehidupan suatu desa, dibatasi oleh batas geografi dan territorial dianggap tidak relevan lagi, karena tidak dapat menjawab tantangan yang diajukan oleh globalisasi. Dengan demikian pengetahuan masyarakat tidak dapat dibatasi lagi hanya sebatas pengetahuan yang terjadi dalam relasisosial yang face-to-face,tetapi juga harus dapat dilihat bagaimana masyarakat dihubungkan oleh teknologi komunikasi (internet), pola konsumsi global,konfigurasi geopolitik yang terus berubah.Hal yang diperbincangkan adalah dimensi spasial dan temporal dari globalisasi hukum dan penelusuran terhadap muncul, mengalir dan pengaruh dari hukum transnasional terhadap arena sosial yang kecil (Benda-Beckmann, et.al, 2005: 9)

Metode penelitian semacam ini pernah ditunjukkan oleh para antropolog yang muncul sebelumnya. Sangatlah signifikan untuk menunjukkan hubungan antara peristiwa pada skala yang lebih luas (makro) dengan peristiwa pada tingkat lokal (mikro), hubungan antara negara dengan individu seperti yang dikemukakan oleh Sally Falk Moore. .".. links local and large-scale matters, the individual and the state, hints at the wide networks and persistent advantage 
of an elite, and the importance of the division of know ledge (Moore,1994:370).Dalam hal ini adalah, bagaimanakah peristiwa sosial, politik dan hukum pada tingkat makro (nasional), termasuk yang dituangkan melalui kebijakan negara, berdampak pada masyarakat lokal.

Berbicara mengenai hubungan antara peristiwa pada skala luas (nasional) dengan peristiwa pada tingkat mikro (lokal), adalah berkaitan dengan keberadaan suatu masyarakat yang dipandang tersusun atas berbagai semiautonomous social field (SASF Bagaimanakah aturan-aturan atau kebijakan yang berasal dari dunia internasional, negara (khususnya dalam bidang pengaturan masalah sumberdaya ) berdampak pada SASF-SASF masyarakat sekitarnya. Dalam hal ini dapat dijelaskan bagaimanakah individu menanggapi peristiwa hukum pada tingkat nasional, internasional, dan berdasarkan pengalamannya atau apa yang diketahuinya mengenai bidang hukum pada tingkat yang makro itu, apakah yang ia lakukan, ketika ia sendiri berhadapan dengan masalah hukum.

Di samping itu, peristiwa tertentu yang terjadi pada waktu tertentu dapat dihubungkan dengan peristiwa lain yang terjadi pada waktu yang lain, dan dapat dipandang sebagai suatu rangkaian (Moore, 1994: 364) It has been reliably reported recently that history and ethnography have often been seen bedded together in the same text. That coupling and complementary of two distinct forms of knowledge has enlivened and enriched both (Moore, 1994: 326) Moore menjelaskan perlunya memberi perhatian kepada proses sejarah yang muncul beberapa dekade yang terkait dengan penelitian arsip. Penelitian lapangan juga merupakan pengalaman sejarah masa kini, sejarah yang sedang dalam proses pembuatan. Dalam hal ini hendaknya dijelaskan mengenai kasus-kasus yang berkaitan dengan konflik mengenai sumberdaya yang pernah terjadi pada masa-masa sebelumnya, misalnya, yang terekam dalam arsip, khususnya vonis-vonis pengadilan, kemudian menghubungkannnya dengan kasus-kasus konflik yang terjadi pada masa sekarang.

\section{a)Pluralisme Hukum}

Pluralisme berasal dari bahasa Inggris: pluralism, terdiri dari dua kata plural (beragam) dan isme (paham) yang berarti beragam pemahaman, atau bermacam-macam paham Untuk itu kata ini termasuk kata yang ambigu (bermakna lebih dari satu). Sedangkan pengertian hukum adalah peraturan atau adat yg secara resmi dianggap mengikat, yg dikukuhkan oleh penguasa atau pemerintah. 
Jadi Pengertian Pluralisme Hukum adalah: Pluralisme hukum (legal pluralism) kerap diartikan sebagai keragaman hukum. Pluralisme hukum adalah hadirnya lebih dari satu aturan hukum dalam sebuah lingkungan sosial.

\section{b).Pluralisme Hukum di Indonesia}

Pluralisme hukum (legal pluralism) kerap diartikan sebagai keragaman hukum. Menurut John Griffiths, pluralisme hukum adalah hadirnya lebih dari satu aturan hukum dalam sebuah lingkungan sosial (Griffiths, 1986:

1). Pada dasarnya, pluralisme hukum melancarkan kritik terhadap apa yang disebut John Griffiths sebagai ideologi sentralisme hukum (legal centralism).Sentralisme hukum memaknai hukum sebagai "hukum negara" yang berlaku seragam untuk semua orang yang berada di wilayah yurisdiksi negara tersebut. Dengan demikian, hanya ada satu hukum yang diberlakukan dalam suatu negara, yaitu hukum negara. Hukum hanya dapat dibentuk oleh lembaga negara yang ditugaskan secara khusus untuk itu. Meskipun ada kaidah- kaidah hukum lain, sentralisme hukum menempatkan hukum negara berada di atas kaidah hukum lainnya, seperti hukum adat, hukum agama, maupun kebiasan-kebiasaan. Kaidah- kaidah hukum lain tersebut dianggap memiliki daya ikat yang lebih lemah dan harus tunduk pada hukum negara (Griffiths, 2005: 71).

Dalam perjalanannya, pluralisme hukum ini tidak terlepas dari sejumlah kritik, di antaranya:

(1) pluralisme hukum dinilai tidak memberikan tekanan pada batasan istilah hukum yang digunakan;

(2) pluralisme hukum dianggap kurang mempertimbangkan faktor struktur sosio- ekonomi makro yang mempengaruhi terjadinya sentralisme hukum dan pluralisme hukum. Selain itu, menurut Rikardo Simarmata, kelemahan penting lainnya dari pluralisme hukum adalah pengabaiannya terhadap aspek keadilan. Lagi pula, pluralisme hukum belum bisa menawarkan sebuah konsep jitu sebagai antitesis hukum negara. Pluralisme hukum hanya dapat dipakai untuk memahami realitas hukum di dalam masyarakat.

\section{c).Gerakan Pluralisme Hukum di Indonesia}

Perkembangan pluralisme hukum dalam gerakan perubahan hukum muncul melalui advokasi- advokasi terhadap masyarakat adat. Dalam konteks ini, pluralisme hukum dipakai untuk membela tanah-tanah masyarakat yang diambil paksa oleh negara atau pelaku swasta (Simarmata, 2005). Hukum adat ditampilkan sebagai lawan dari hukum negara yang memberi keabsahan 
perampasan-perampasan tanah adat. Lagi pula, dalam UUPA ada peluang melalui aturan yang mengakui keberadaan tanah-tanah adat (ulayat).Singkatnya, konsep pluralisme hukum dipakai untuk mengangkat kembali keberadaan hukum adat, dalam upaya untuk melindungi sumber daya alam yang dimiliki masyarakat adat dari perampasan-perampasan yang diabsahkan hukum negara.

Lebih jauh lagi, pluralisme hukum dipakai untuk mendorong pengakuan keberadaan masyarakat adat oleh negara. Salah satu keberhasilan gerakan ini adalah menggolkan aturan mengenai pengakuan dan penghormatan kesatuankesatuan masyarakat hukum adat hak-hak tradisionalnya dalam Pasal 18B UUD 1945 pada amandemen kedua tahun 2000. Selain itu, kemunculan TAP MPR Nomor IX/2001 tentang Pembaharuan Agraria, yang di dalamnya diatur juga tentang masyarakat adat, juga tidak terlepas dari pengaruh pluralisme hukum. Sejak munculnya aturan ini, hampir semua produk hukum negara yang berkaitan dengan sumber daya alam memuat aturan mengenai masyarakat adat ini.

Di tataran praktis, gerakan untuk mendorong pengakuan masyarakat adat semakin masih dilakukan aktivis-aktivis pro-masyarakat adat. Di antaranya dengan melakukan pemetaan wilayah-wilayah adat di sejumlah tempat dan pendokumentasian hukum-hukum adat. Karena, dua hal inilah yang menjadi syarat utama untuk diakuinya keberadaan masyarakat adat.Selain itu, gerakan ini juga mendorong pemerintah-pemerintah daerah mengakui masyarakat adat melalui pembentukan sejumlah regulasi daerah. Di sisi lain, pemberlakuan otonomi daerah juga semakin memberi angin segar untuk gerakan ini. Lebih jauh lagi, gerakan penggiat pluralisme hukum juga mencoba merambah ranah penyelesaian sengketa, yaitu dengan mendorong adanya koordinasi pengakuan terhadap lembaga-lembaga penyelesaian hukum adat (peradilan adat). Hal ini dianggap sebagai salah satu jawaban terhadap situasi lembaga penyelesaian sengketa negara (pengadilan) yang bobrok, yang dinilai tidak dapat memberikan keadilan substantif. Gerakan ini intinya menawarkan untuk membiarkan masyarakat menyelesaikan persoalannya sendiri melalui peradilan adat tanpa melalui melibatkan pengadilan.

\section{d). Irelevansi Pluralisme Hukum bagi Indonesia Sekarang Ini}

Gerakan perubahan hukum di Indonesia dengan menggunakan pluralisme hukum sebagai pijakan, telah melangkah cukup jauh. Salah satunya adalah dengan diakuinya hak-hak masyarakat adat, termasuk hukumnya, dalam konstitusi. Masyarakat Indonesia memang merupakan masyarakat yang 
majemuk, tetapi bukan berarti bahwa pluralisme hukum merupakan jawaban atas adanya problem hukum di Indonesia.

Pluralisme hukum jelas mengakomodasi nilai-nilai tersebut, dan telah menjadi ancaman bagi demokratisasi di Indonesia. Pengabaian aspek keadilan dalam pluralisme hukum membuat cakupan hukum dalam pengertian pluralisme hukum juga hampir tidak mengenal batas. Sepanjang aturan tersebut dilahirkan dan diberlakukan dalam wilayah tertentu, ia sudah dapat dikatakan sebagai hukum. Tidak begitu penting apakah aturan tersebut dilahirkan dengan proses dominasi atau dimaksudkan untuk meminggirkan kelompok-kelompok tertentu (Simarmata, 2005).

Singkatnya, semua nilai-nilai, termasuk nilai-nilai negatif, dapat tumbuh dan berkembang melalui pluralisme hukum.Hal ini sebenarnya sudah terjadi ketika sejumlah peraturan daerah (perda) yang secara substantif meminggirkan kelompok-kelompok tertentu, berlaku di sejumlah daerah.

\section{C.PENUTUP}

Pluralisme hukum bisa menjadi ancaman serius bagi proses demokrasi di Indonesia. Dengan alasan pluralisme hukum, semua produk hukum dapat dipakai untuk menyuburkan nilai-nilai feodalisme, otoritarianisme, ketidakadilan ekonomi, dan bahkan dijadikan jalan bagi totalitarianisme. Indonesia merupakan masyarakat yang majemuk, Namun kita belum memiliki konstitusi yang kuat untuk menopang kemajemukan. Feodalisme masih begitu kental dalam seluruh segi kehidupan masyarakat kita. Kita masih juga masih belum lepas dari bayang- bayang otoritarianisme yang masih menghantui kita, ditambah dengan ancaman munculnya kembali totalitarianisme semakin menguat akhir-akhir ini. Oleh karena itu, pluralisme hukum, bagaimanapun juga, tidak relevan dengan kondisi sosial-politik Indonesia.

Pluralisme hukum bisa menjadi ancaman serius bagi proses demokrasi di Indonesia. Dengan alasan pluralisme hukum, semua produk hukum dapat dipakai untuk menyuburkan nilai-nilai feodalisme, otoritarianisme, ketidakadilan ekonomi, dan bahkan dijadikan jalan bagi totalitarianisme. Indonesia merupakan masyarakat yang majemuk, Namun kita belum memiliki konstitusi yang kuat untuk menopang kemajemukan. Feodalisme masih begitu kental dalam seluruh segi kehidupan masyarakat kita. Kita masih juga masih belum lepas dari bayang- bayang otoritarianisme yang masih menghantui kita, ditambah dengan ancaman munculnya kembali totalitarianisme semakin 
menguat akhir-akhir ini. Oleh karena itu, pluralisme hukum, bagaimanapun juga, tidak relevan dengan kondisi sosial-politik Indonesia.

Pendekatan pluralisme hukum dalam perspektif global mengajak kita untuk berhati-hati dalam menyikapi keragaman hukum. Kita tidak lagi dapat membuat mapping of legal universe, menarik garis batas yang tegas untuk membedakan suatu entitas hukum tertentu dari yang lain. Kita sukar untuk menarik batas yang tegas antara hukum internasional, nasional dan lokal, karena sistem hukum yang berasal dari tataran yang berbeda-beda itu saling bersentuhan, berinteraksi, berinter-relasi, berpengaruh, menyesuaikan diri dan mengadopsi satu sama lain secara luas. Hal itu sangat kelihatan dari bagaimana hukum internasional bahkan memberi dampak sampai kepada masyarakat lokal dan mendiseminasi nilai-nilaihumanitarian, demokrasi, rule of law, dan akuntabilitas internasional. Atau sebaliknya, hukum lokal juga dapat memberi kontribusinya kepada sistem hukum dalam skala internasional atau hukum lokal dari masyarakat lain.

Pendekatan pluralisme hukum dalam perspektif global juga menunjukkan kepada kita pentingnya untuk melihat para aktor dan organisasi yang memainkan peranan yang sangat penting sebagai agent terjadinya globalisasi hukum. Interaksi di antara para aktor dalam relasi- relasi kekuasaan dapat diamati dalam ruang-ruang negosiasi yang menyebabkan interaksi tersebut terus menerus diproduksi dan diubah oleh para aktor.Secara metodologis, pendekatan pluralisme hukum berperspektif global memberi sumbangan yang sangat berharga karena masyarakat tidak lagi harus dipelajari dalam ruang geografi dan teritori yang terbatas. Masyarakat harus dilihat dalam arena yang multi-sited, karena terhubung oleh relasi bisnis, politik, sosial, dan dihubungkan oleh penemuan teknologi komunikasi yang sangat menakjubkan (internet). 


\section{DAFTAR PUSTAKA}

Darmini Roza dan Laurensius Arliman S, Peran Pemerintah Daerah Di Dalam Melindungi Hak Anak Di Indonesia,Masalah-

Masalah Hukum, Volume 47, Nomor 1, 2018.https://doi.org/10.14710/mmh.4 7.1.2018.10-21

Laurensius Arliman S, Peranan Metodologi Penelitian Hukum di Dalam Perkembangan

Ilmu Hukum di Indonesia,Soumatera Law Review, Volume 1, Nomor 1, 201. http://doi.org/10.22216/soumlaw.v1i1.3346.

Laurensius Arliman S, Peran Badan Permusyawaratan Desa di Dalam Pembangunan Desa dan Pengawasan Keuangan Desa, Padjadjaran Journal of Law, Volume 4, Nomor 3, 2017. https://doi.org/10.15408/jch.v4i2.3433.

Laurensius Arliman S, Penanaman Modal Asing Di Sumatera Barat Berdasarkan Undang- Undang Nomor 25 Tahun 2007 Tentang Penanaman Modal, Supremasi Hukum, Volume 1,Nomor 1, 2018.http://dx.doi.org/10.36441/hukum.v1i01.102 .

Laurensius Arliman S, Memperkuat Kearifan Lokal UntukMenangkal Intoleransi

Umat Beragama Di Indonesia,Ensiklopedia of Journal, Volume 1, Nomor 1, 2 018,https://doi.org/10.33559/eoj.v1i1.18.

Laurensius Arliman S, Perkawinan Antar Negara Di Indonesia Berdasarkan Hukum Perdata Internasional, Kertha Patrika,Volume 39, Nomor 3, 2017, https://doi.o rg/10.24843/KP.2017.v39.i03.p03.

Laurensius Arliman S, Partisipasi Masyarakat Di DalamPengelolaan Uang Desa Pa sca Undang-Undang Nomor 6 Tahun 2014 Tentang Desa, Jurnal Arena Hukum, Volume 12, Nomor

2019,https://doi.org/10.21776/ub.arenahukum.2019.01202.5.

Laurensius Arliman S, Mewujudkan Penegakan Hukum YangBaik Di Negara Huk um Indonesia, Dialogica Jurnalica,Volume 11, Nomor 1, 2019,https://doi.org/ 10.28932/di.v11i1.1831.

Laurensius Arliman S, Mediasi Melalui Pendekatan Mufakat Sebagai Lembaga Alternatif Penyelesaian Sengketa UntukMendukung Pembangunan Ekonomi Nasional, UIR LawReview, Volume 2, Nomor 2, 2018, https://doi.org/10.2529 9/uirlrev.2018.vol2(02).1587

Laurensius Arliman S, Peranan Filsafat Hukum DalamPerlindungan Hak Anak Ya ng Berkelanjutan SebagaiBagian Dari Hak Asasi Manusia, Doctrinal, Volume 1,Nomor 2, 2016.

Laurensius Arliman S, Ni

Putu

Eka

Dewi, Protection ofChildren and Women's Rights in Indonesia through

International Regulation Ratification, Journal of Innovation, Creativity and Change Volume 15, Nomor 6, 2021.

Laurensius Arliman S, Gagalnya Perlindungan Anak Sebagai Salah Satu Bagian Dari 
Hak Asasi Manusia Oleh OrangTua Ditinjau Dari Mazhab Utilitarianisme, Jur nal Yuridis,Volume 3, Nomor 2, 2016,http://dx.doi.org/10.35586/.v3i2.180.

Laurensius Arliman S, Tantangan Pendidikan Kewarganegaraan Pada Revolusi 4.0, Jurnal Ensiklopedia Sosial Review,Volume 2, Nomor 3, 2020. 